\title{
An IFIM Experience in the Toyogawa-River Japan
}

\author{
Shunroku Nakamura ${ }^{(1)}$, Akihiko Yabuki ${ }^{(2)}$, and Noriyuki Koizumi ${ }^{(3)}$ \\ Corresponding author: Shunroku Nakamura, roku@gakushikai.jp
}

\begin{abstract}
In order to evaluate a new "Normality" Preservation Flow (NPF: a kind of instream flow) configuration in the Toyogawa-river, we carried out nearly the full IFIM process, even though the analysis was limited to the summer season and the adult stage of some fish species. We employed three kinds of time series of flow in 1967 and 1979 representing three conditions: 1) a flow configuration where no dams and diversion weirs are installed, 2) the present state, and 3) addition of one large new dam, and the NPF configuration is changed according to a government Ministry proposal. The results of the analysis suggest that the proposed condition might give a fairly good increase of fish habitat for some species downstream of the dam, even though some flushing flows would be expected to occur for shorter intervals in fish spawning seasons than the current condition.
\end{abstract}

Key word. - Dam operating plan, flow assessment, habitat suitabily criteria, IFIM, PHABSIM, Toyogawa River

\section{INTRODUCTION}

Recently in Japan, several changes have been occurring in management of streams with water projects. These include 1) legislation in 1988 setting minimum flow rates (of $0.1-0.3 \mathrm{~m}^{3} / \mathrm{s}$ per $100 \mathrm{~km}^{2}$ ), called the "catchment area discharge" for preservation of the downstream environment at power dams for new projects and renewing water rights, 2) initiation of many new projects termed "more-naturalized repair works" since 1990, and 3) revision of the River Act in 1997. The amended River Act includes: 1) conservation of the stream environment is now one of the purposes of the law, and 2) public participation is now required in planning of development within the river environment.

One example of public participation in planning of development is a reviewing committee on the management plan for the Toyogawa River basin that was established in 1998. One of the major subjects of discussion in

(1) Hamada 67-2, Omma Mito-cho, Aichi-pref., 441-0311 Japan

(2) Ken-Kyousai-jyutaku 301, Sato 2605, Ohguchi-city Kagoshima 895-2511 Japan

(3) Namiki 2-125-102, Tsukuba-city 305-0044 Japan 
the committee was a big dam, which was proposed by the Ministry of Land, Infrastructure, and Transport (Ministry of LIT). According to the new dam plan, the dam will contribute not only to flood control and water resources development but also to supply more instream/environmental flow downstream of some existing major dams and diversion weirs in the Toyogawa system.

In order to evaluate the new "Normality" Preservation Flow (NPF: meaning the flow that is the minimum flow to preserve the "normal" function of a stream) configuration in the Toyogawa-river, we carried out nearly the complete IFIM process. As described below, the analysis was limited to the summer season and the adult life stage of selected fish spe- cies. In this paper, we report a brief outline of the IFIM experience.

\section{THE TOYOGAWA RIVER BASIN}

Figure 1 shows the Toyogawa River Basin (catchment area: 724 square $\mathrm{km}$, length of the main stream: $77 \mathrm{~km}$ ), focusing on the major diversion facilities. As shown in the figure, there are 6 dams and 2 diversion weirs and one proposed dam ("Shidara-dam", height: $129 \mathrm{~m}$, total storage volume: 100 million cubic meters, catchment area at the dam-site: 62 sq. km) near the upstream-most portion of the main stem.

The main stem joins the Uregawa River at approximately $30 \mathrm{~km}$ from the river mouth, then reaches a key

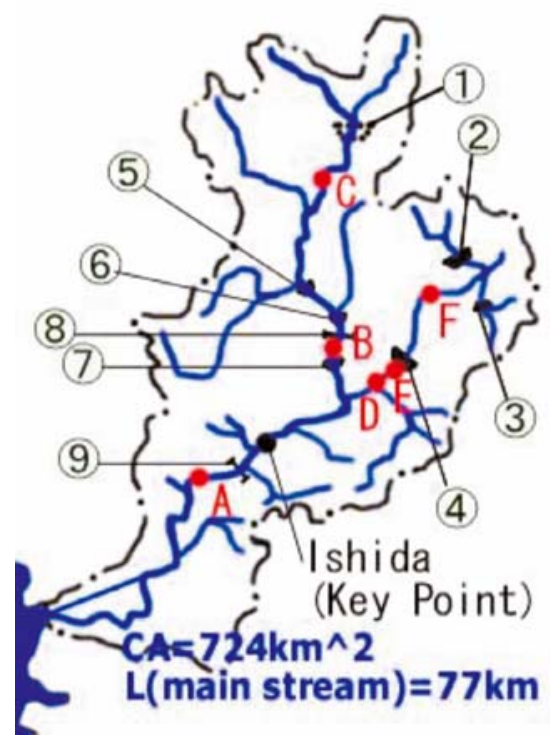

$\begin{array}{ll}\text { Dam: } & \text { (1) Shidara-dam (under planning) } \\ & \text { (2) Ure-dam; (3) Oshima-dam } \\ & \text { (4) Ohno-dam } \\ & \text { (5) (7) small electric-power dams } \\ \text { Diversion } & \text { (8) Kansa-gawa Ohzeki } \\ \text { Weir: } & \text { (9) Muro-Matsubara Tohsyukou } \\ \text { PHAB_site: A:Ejima, B:Jizousita, C:Seireicyu } & \\ & \text { D:Hourai-ouhashi } \\ & \text { E:Ohonodam-sita,F:Miyasitabashi }\end{array}$

Fig. 1. - The Toyogawa River basin. 


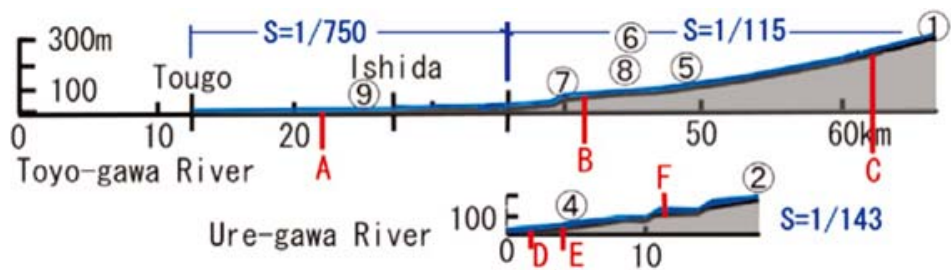

Fig. 2. - Longitudinal section of the main stream of the Toyogawa and Uregawa.

point for flood control - the NP-Flow control point -, at Ishida, $27.6 \mathrm{~km}$ from the river mouth. Downstream of Ishida the bed slope is much gentler than of the slope in the upstream areas (Fig. 2), and levees are installed on both sides.

The Toyogawa basin may be divided into 3 sub-basins: 1) Toyogawadownstream basin, 2) Toyogawa-upstream (called "Kansagawa") basin, and 3) Uregawa basin. Or, from the view point of stream characteristics, we may classify these streams into 3 types: 1) downstream levee-installed stream, 2) upstream mountainous stream, and 3) the dewatered segment downstream of Ohno-dam (Photo 1).

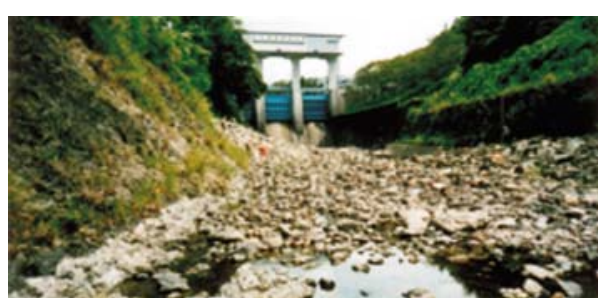

Photo 1. - Dewatered segment downstream of Ohno-dam.

\section{"PHAB STUDY" AND \\ DEVELOPMENT OF HSC FOR THE TOYOGAWA RIVER}

\section{Study Sites}

Prior to the IFIM implementation, in order to obtain habitat suitability criteria (HSC) for the fishes living in the Toyogawa basin, we carried out fish habitat research. We called this work the "PHAB-study" and conducted the study at the six sites marked as A - F in Fig. 1 (Photo $2-7$ ), in July and August in 1998 and 1999.

Among the 6 sites, D and $\mathrm{E}$ are located in the "dewatered" stream downstream of Ohno-dam, where normally there is almost no flow as shown in Photo 1. This occurs because Ohno-dam is not yet required to release the Obligated Conservation Flow Release (OCFR). During our PHAB-studies, however, some small flows were occasionally released from the Ohno-dam, as shown in Photo 6, because the Kansa-gawa Ohzeki (diversion weir: (8) in Fig. 1) and Ohno-dam were already connected by a pipe-line and their coordinated operation had already started before that time. 


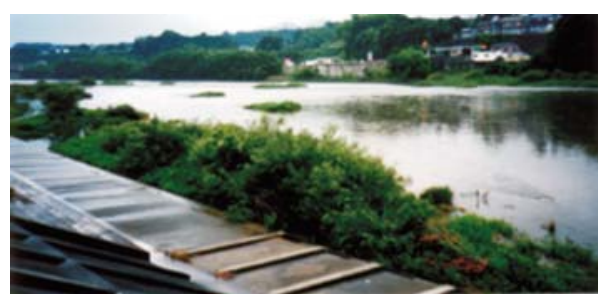

Photo 2. - Site A: Ejima

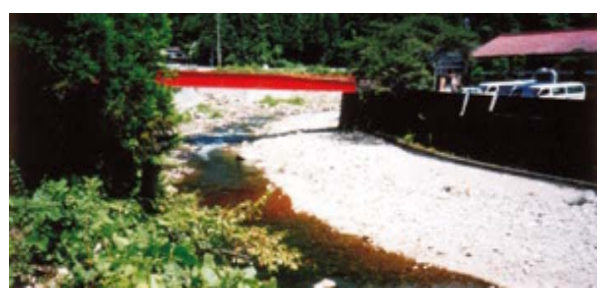

Photo 4. - Site C: Seireicyu.

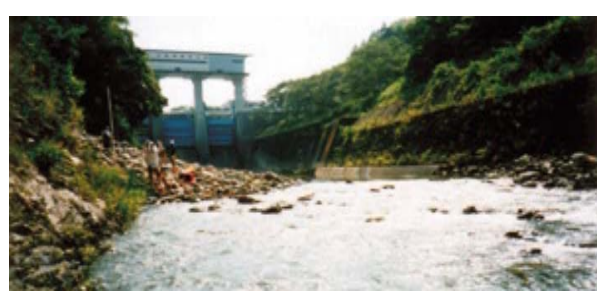

Photo 6. - Site E: Ohnodam-shita.

The flow rates at each site are shown in Table 1 together with the sampling data for the major fish species.

Generalization of the Habitat

Suitability Criteria

In each of the PHAB-studies, we obtained many HSCs (Category III criteria based on the forage ratio) at each site for the adult life stage of the following 5 species: Ayu Plecoglossus altivelis, Ugui (a kind of dace)

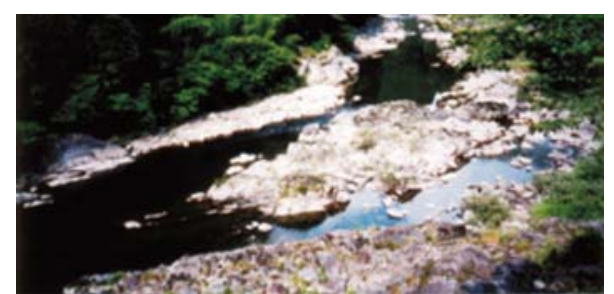

Photo 3. - Site B: Jizoushita.

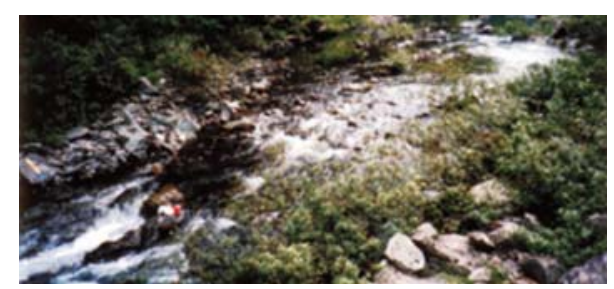

Photo 5. - Site D: Houraibashi.

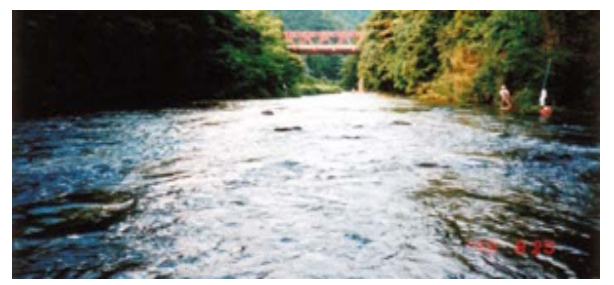

Photo 7. - Site F: Miyashitabashi.

Leuciscus (Tribolodon) hakonensis, Oikawa Zacco platypus, Kawamutsu Zacco temmincki, and Yoshinobori Rhinogobius sp. CB. These, so called "site-dependent" HSCs are, however, of course all somewhat different for different occasions even for the same species and same site. The differences persist even though they are verified at each site using the Thomas-Bovee (1993) method.

Therefore we tried the following 4 plans/ideas: 
Table 1. - Flow rate and number of observed fish in the PHAB-studies.

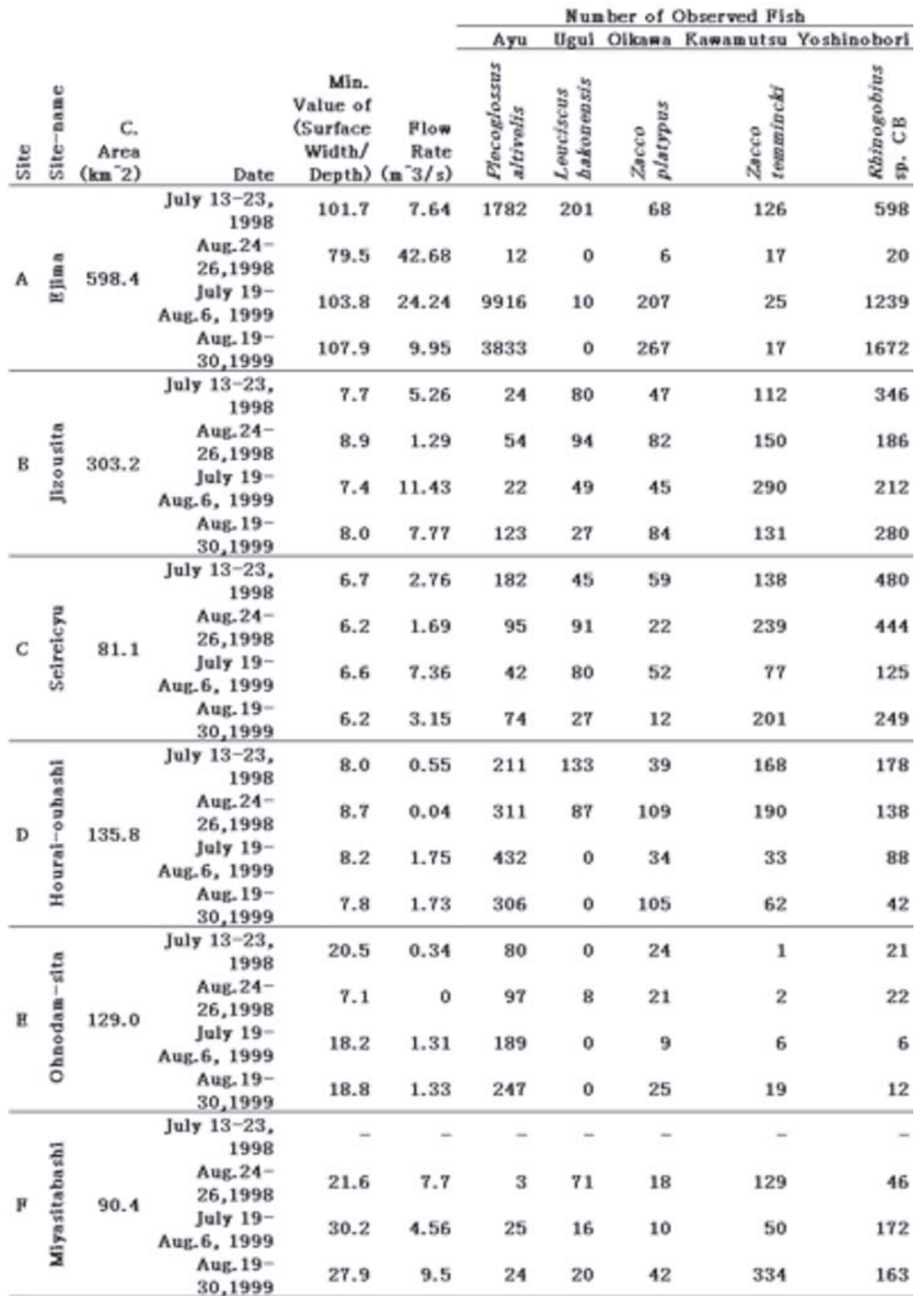


Plan A1: All data were used for making generalized HSCs for each specific species.

Plan A2: The raw data were classified into 3 types of stream, i.e. 1) the downstream levee-installed stream, 2) the upstream mountainous stream, and 3) the dewatered segment downstream of Ohno-dam. Then the HSC were generated in each stream-type using all of the data for that stream type.

Plan B1: At each PHAB-study we selected the data, and only the selected data were used to develop HSC. The selection was made based on a) the Thomas-Bovee method of verification, b) Cramer's coefficient of association, and c) correlation coefficient between WUA and used-cell area.

Plan B2: This plan was similar to the B1 but the correlation c) above was not evaluated.
In methods B1 and B2, the generalized $\mathrm{HSC}$ are such that the effective habitat range (range of $\mathrm{SI}=1$ ) covers all of the $\mathrm{SI}=1$ range of the selected site-dependent HSC, as shown in Fig. 3.

Then, in order to determine which plans might be the best, we compared all of the generalized HSC thus obtained, based on items a) - c) above. Figure 4 shows an example of the selected HSC (HSC Toyogawa version) for the IFIM implementation.

\section{IFIM IMPLEMENTATION}

\section{Time Series of Flow}

We employed three kinds of flow time series in 1967 and 1979 representing three alternative conditions: 1) a flow configuration with no dam/diversion-weir installed, 2) the present

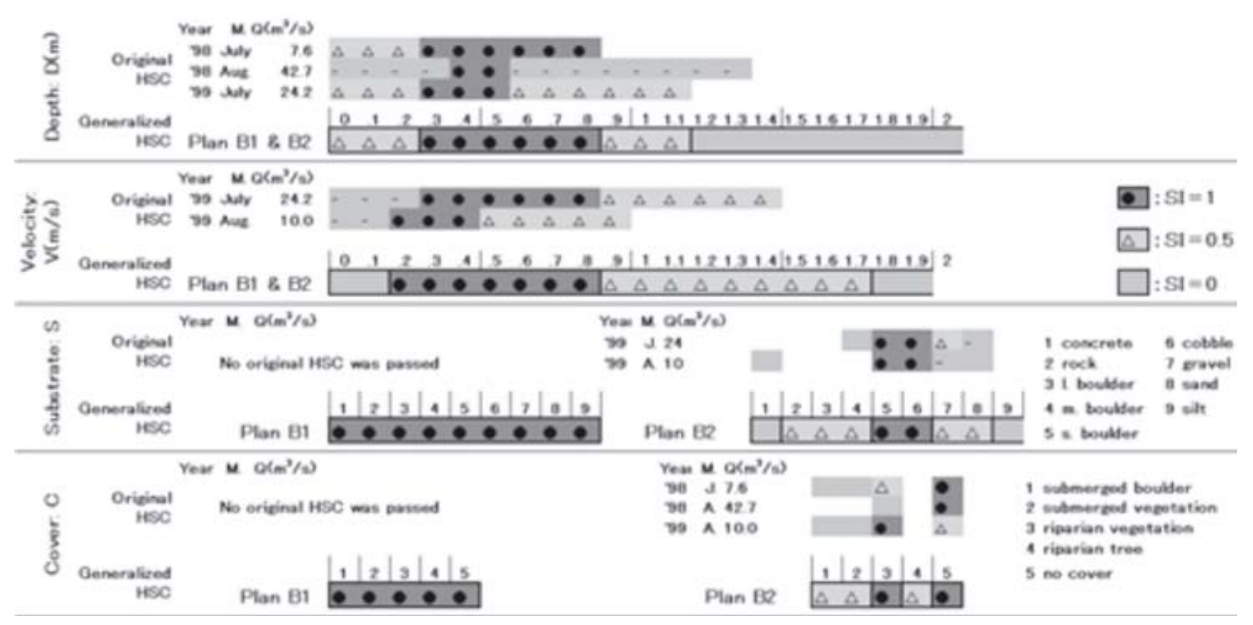

Fig. 3. - Generalization of HSC by Plan B1 and B2. 


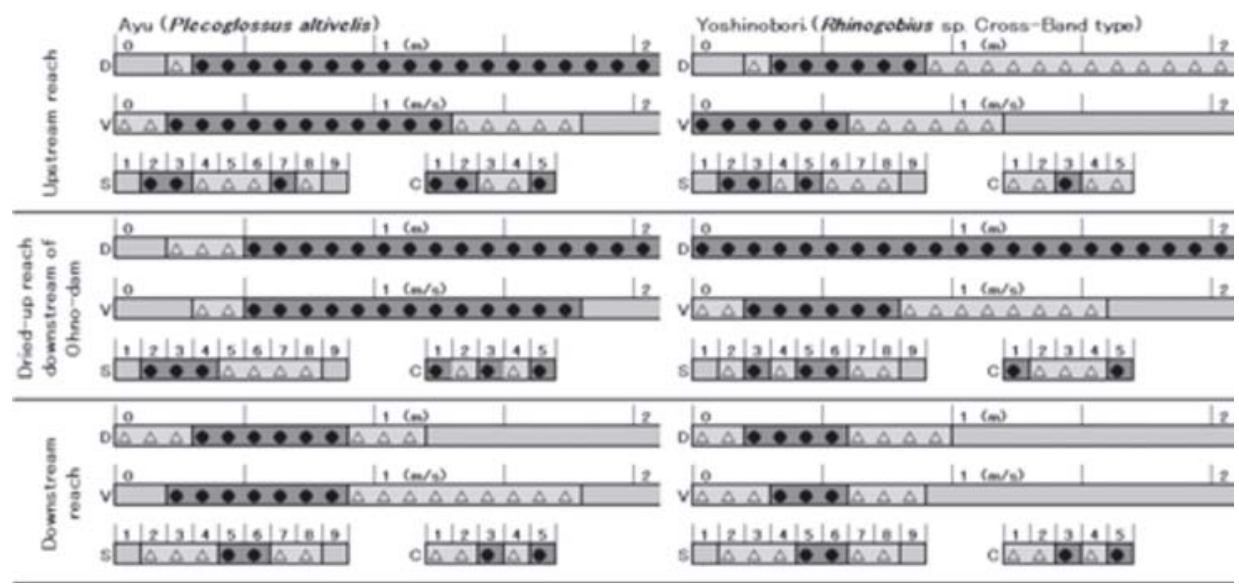

Fig. 4. - Example of the HSC Toyogawa version.

condition, and 3) an alternative where one big dam is installed and the NPF configuration is changed according to a government Ministry proposal, as shown in Fig. 5.

We excluded the six months of the winter season (January 1 - March 31 and October 1 - December 31), because as yet we have no biological data for winter. Then, we modified the remaining time series in two ways.
First, the minimum flow in every continuous three day period (minQ3d) was assumed to be constant during those three days. That is, we assumed that increasing the flow for such a short time as one or two days could not be effective. In the second modification the periods when the flows at Ishida exceed $15 \mathrm{~m}^{3} / \mathrm{s}$ were assumed to be above "flood" stage, then only the remained periods were

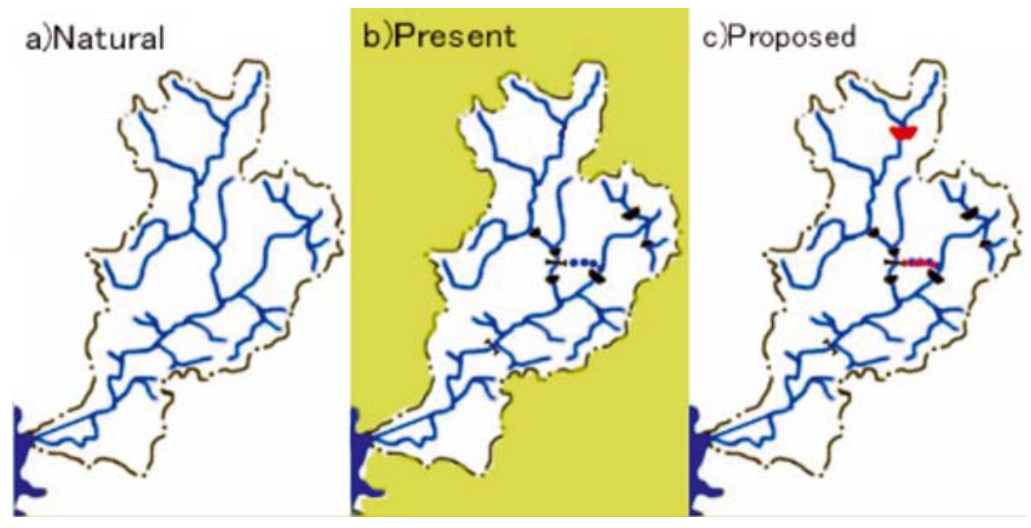

Fig. 5. - Three cases which we evaluated. 

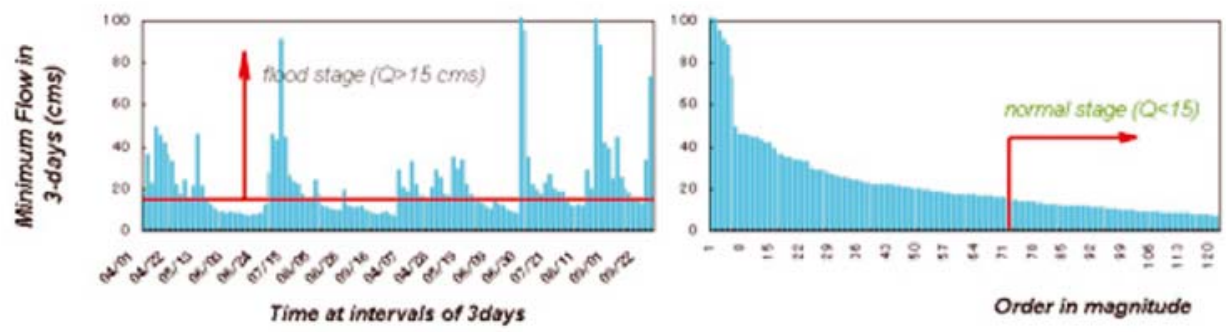

Fig. 6. - Time series (left) and duration curve (right) of minimum flows in 3 days (minQ3d) at Ishida in summer season in 1967 and 1979.

selected as "normal" flow stages to be analyzed (Fig. 6).

We chose only 9 flow values from the remained time series for the analysis described below. To select these flows, first we plotted the nonexceedance probability of the original/observed values at Ishida. Then, in order to obtain a straight line, the temporary values which are generated by adding a constant value to the original values (Iwai method), as shown in Fig. 7. Based on those nonexceedance calculations, we chose the following 9 values: Qave (average value of discharge) $+2 \sigma$ (standard deviation), Qave $+3 / 2 \sigma$, Qave $+\sigma$, Qave + 1/2 $\sigma$, Qave, Qave - 1/2 $\sigma$,

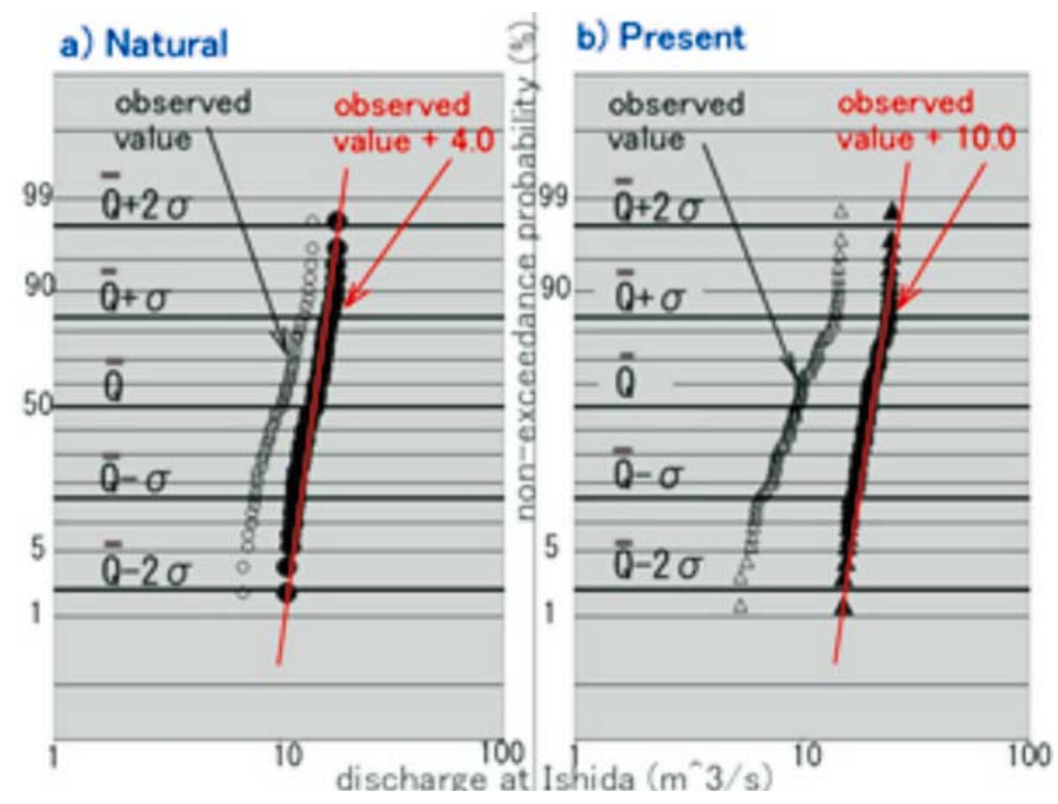

Fig. 7. - Non-exceedance probability of discharge at Ishida (for the non-winter time series). 
Qave - $\sigma$, Qave - 3/2 $\sigma$, and Qave $2 \sigma$.

\section{Stream Network Model}

We divided the Toyogawa basin (actually upstream of Tougo) into more than 40 small basins and developed a stream-network model as shown in Fig. 8.

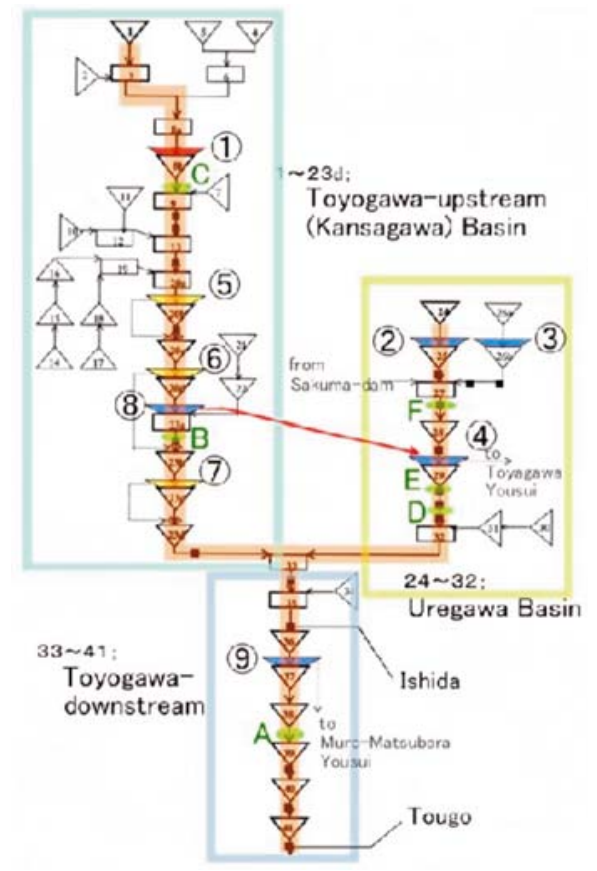

$$
\begin{array}{ll}
\text { Dam: } & \text { (1) Shidara-dam (under planning) } \\
& \text { (2) Ure-dam; (3) Oshima-dam } \\
& \text { (4) Ohno-dam } \\
& \text { (5) (1) small electric-power dams } \\
\text { Diversion } & \text { (8) Ransa-gawa Ohzeld } \\
\text { Weir: } & \text { (\$) Muro-Matsubara Tohsyukou } \\
\text { PHAB_site: A:Ejma, B:Jizousita, C:Seireicyu } & \\
& \text { D:Hourai-ouhashi } \\
& \text { E:Ohonodam-sita,F:Miyasitabashi }
\end{array}
$$

Fig. 8. - Toyogawa network model ("proposed" version).

(Note: some water diversions from Sakumadam to the Uregawa are only for emergency dewatered periods at Ohno-dam)
We calculated the water surface profile, velocity distribution, and weighted usable area (WUA) etc. for the 9 selected flows on the main stem of the Toyogawa and Uregawa (orange colored line in Fig. 8) where cross-sectional data were available at every $200 \mathrm{~m}$. We performed the same calculations for the (more detailed) PHAB-sites. The discharge values were derived at every major point based on the observed values at some control points such as dams and diversion weirs and on proportional allotment based on the subbasin's area elsewhere. Also, the Manning's $n$ value was derived based on the bed materials as follows: from the river mouth $(0 \mathrm{~km})$ to Tougo $(13.2 \mathrm{~km}): \mathrm{n}=0.03$, from $13.2 \mathrm{~km}$ to $57.2 \mathrm{~km}: \mathrm{n}=0.05, \quad 57.2 \mathrm{~km} \quad-$ $66.9 \mathrm{~km}: \mathrm{n}=0.10$, and the Uregawa: $\mathrm{n}=0.05$.

For these calculations we used the "BWM_WUA (version 5.18)" model developed by Prof. H. Asakusa, Tsukuba Technical College (Asakusa et al. 2003).

\section{Cell Division and Velocity \\ Distribution}

The cell division was made based on the cross section shape and the calculated water depth; we divided at every $0.2 \mathrm{~m}$ change in water depth, as shown in Fig. 9.

We calculated the velocity distribution at each cross section using the following equation:

$\mathrm{Vi}=\alpha$ di and $\mathrm{Q}=\Sigma$ (bi di $\mathrm{Vi}$ ), where $\mathrm{V}$ : velocity (unknown), $\alpha$ : constant value (supposed), d: water depth (known), 


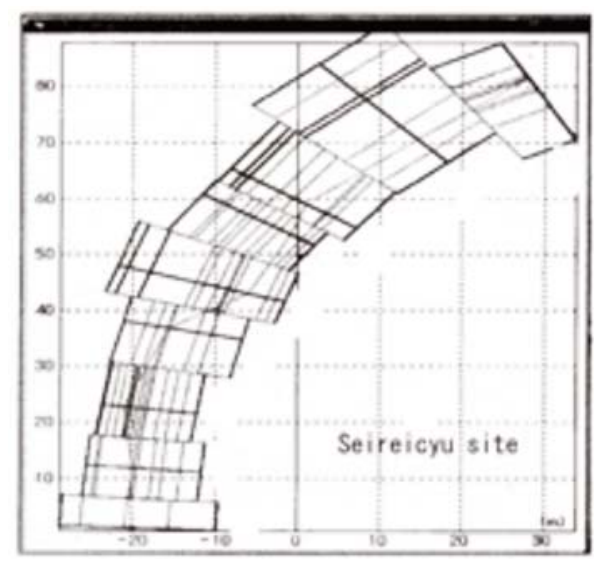

Fig. 9. - Example of cell division.

Q: flow rate (known), b: water surface width of cell (known), and i: $1-\mathrm{N}$ in the case to be divided to $\mathrm{N}$ (known).

Figure 10 shows a verification graph for the velocity calculation, in which the relationships between observed values and calculated values are compared with the cases where Chezy-type and Manning type equations were used; as shown in the figure the linear-equation noted above gave the highest correlation.
Verification of the Calculated

WUA

Figures 11 and 12 show verification graphs as of WUA. As shown in the figures, our calculations using the generalized HSC produce a relatively good fit.

\section{EVALUATION OF THE NEW "NORMALITY" PRESERVATION FLOW CONFIGURATION}

According to the proposal by the Ministry of LIT, the minimum NP Flow or Obligated Conservation Flow Release (OCFR) will be changed to $1.3 \mathrm{~m}^{3} / \mathrm{s}$ from the present value of $0 \mathrm{~m}^{3} / \mathrm{s}$ at Ohno-dam through coordinated operation between the Kansagawa Ohzeki and Ohno-dam. Similarly OCFR would increase from $2.0 \mathrm{~m}^{3} / \mathrm{s}$ to $5.0 \mathrm{~m}^{3} / \mathrm{s}$ at the MuroMatsubara Tosyukou, and from $0.0 \mathrm{~m}^{3} / \mathrm{s}$ to $3.3 \mathrm{~m}^{3} / \mathrm{s}$ at the Kansagawa Ohzeki, after completion of the new Shidara-dam.
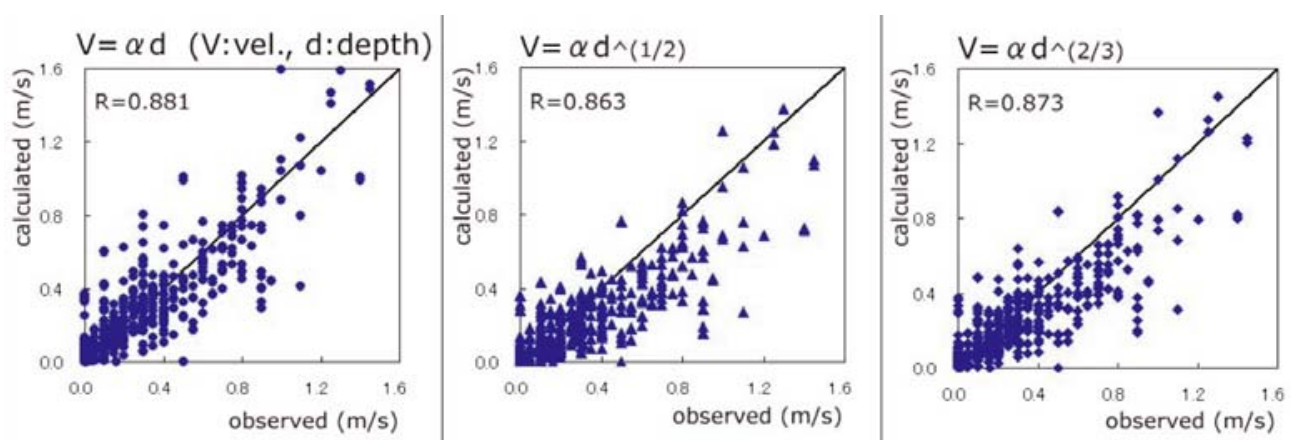

Fig. 10. - Correlations between observed velocity values and calculated values. 

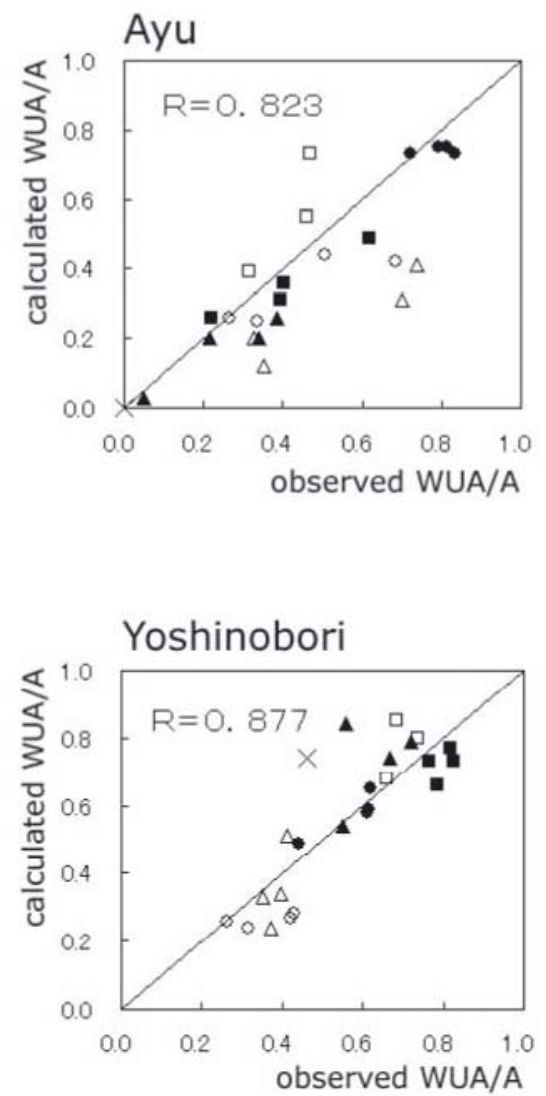

Fig. 11. - Comparison between calculated and observed (= site-dependent HSC-used) values as of WUA/A for Ayu at selected PHAB-study sites (A: total area of each site, calculated in "calculated" and observed in "observed")

Fig. 12. - Comparison between calculated and observed (site-dependent HSC-used) values as of WUA/A for Yoshinobori at selected PHAB-study sites

Fig. 13. - Comparison between calculated WUA and observed total area of fish-used cells at selected PHAB-study sites.

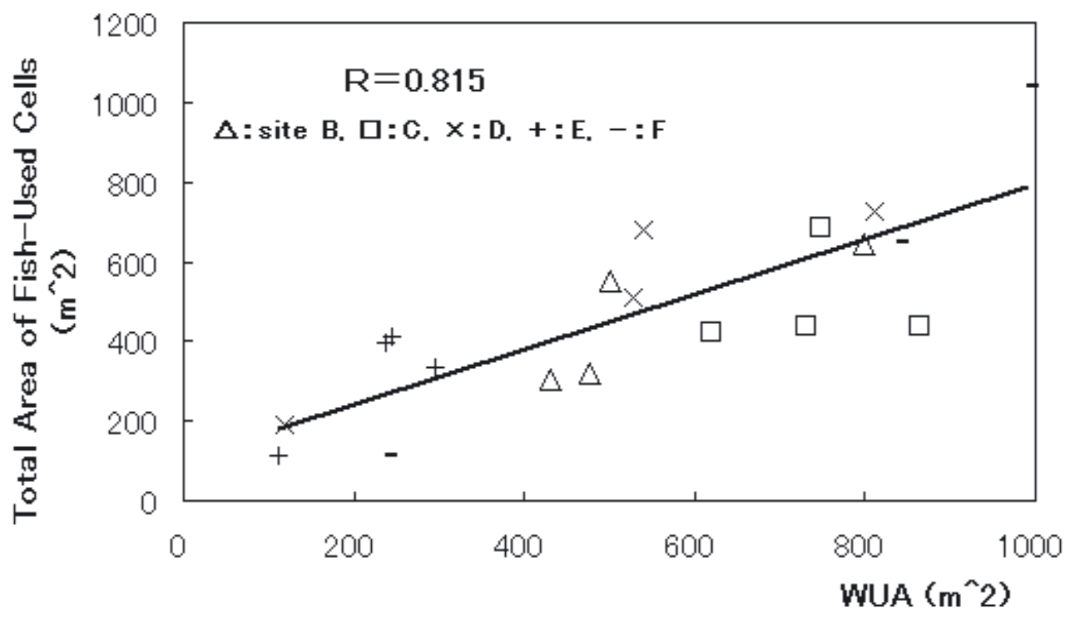



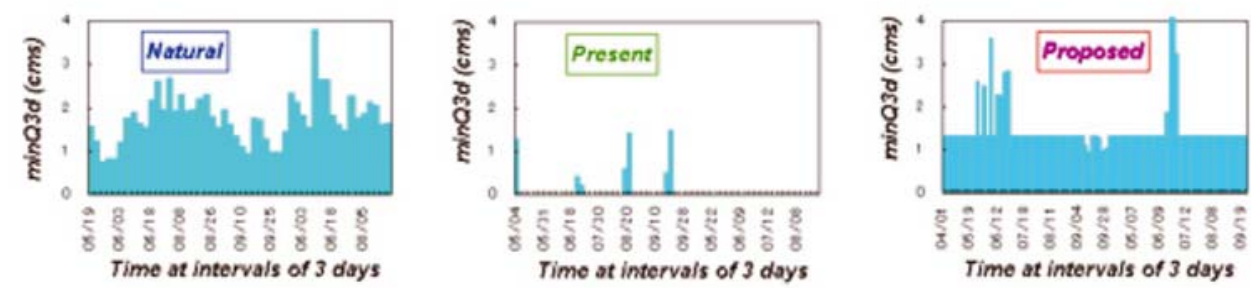

Fig. 14. - Time series of minQ3d in summer normal flow stage at the downstream reach of Ohnodam.
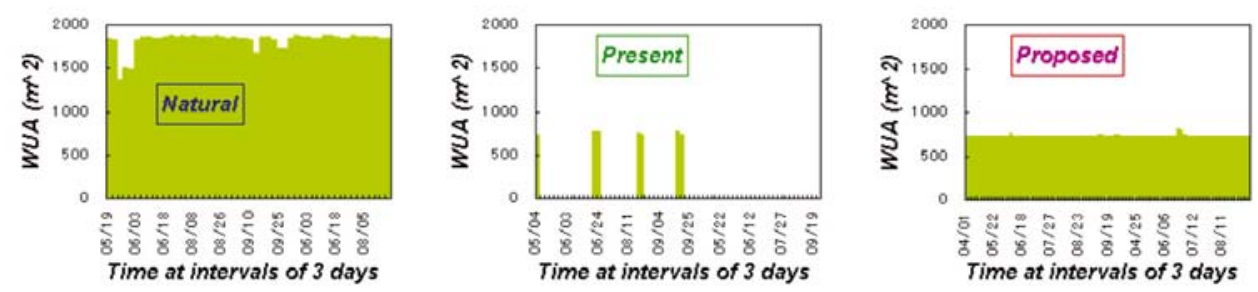

Fig. 15. - Habitat time series for adult Ayu in summer normal flow stage at the downstream reach of Ohno-dam.

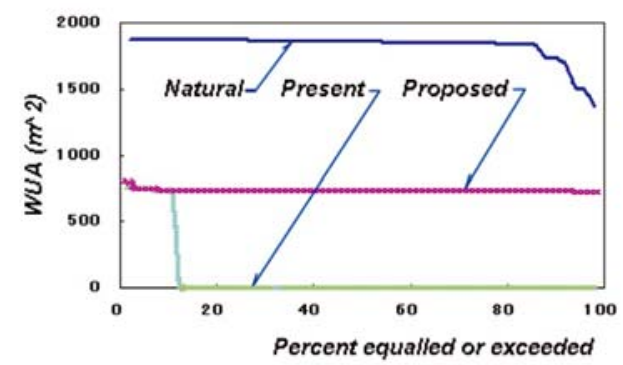

Fig. 16. - Duration curves of effective habitat area (WUA) for Ayu at the downstream reach of Ohno-dam.

Let us first consider the changes in the reach downstream of Ohno-dam, shown in Figs. 14, 15 and 16.

From these results, we may conclude that: 1) the proposed condition might give a fairly good increase of fish habitat for some fishes downstream of the dam, 2) these increases occur even though some flushing flows would be expected to occur for shorter intervals during fish spawning seasons.

Next, let us consider the total changes of the fish habitat for the major swimming fish such as Ayu, Ugui, etc. and for the bottom-dwelling fish such as the Yoshinobori. The changes are compared and summarized in Figs. 17 and 18. that:

From these figures, we conclude

1) The proposed condition might provide better habitat in the reaches downstream of the dams for swimming fish,

2) however, the natural (no dam) condition might be better in the downstream reach of the Toyogawa River 


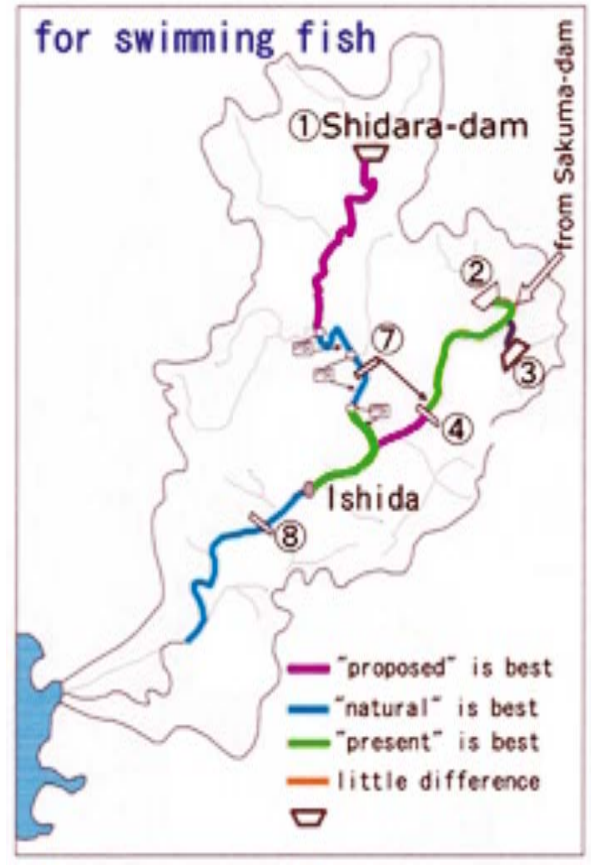

Fig. 17. - Summarized habitat change for major swimming fish in summer.

and downstream of the two small power-dams.

3) Regarding bottom-dwelling fish, only a little change might be expected, except downstream of the Ohno-dam as mentioned above.

4) Again it should be noted that natural condition could also be better for bottom-dwelling fish in the downstream reach of the Toyogawa River.

Thus, we may give such recommendation that:

1) Some more flexible operation/ flow release would be considered for the downstream reaches.

2) For the sake of making use of the better habitat for swimming fish

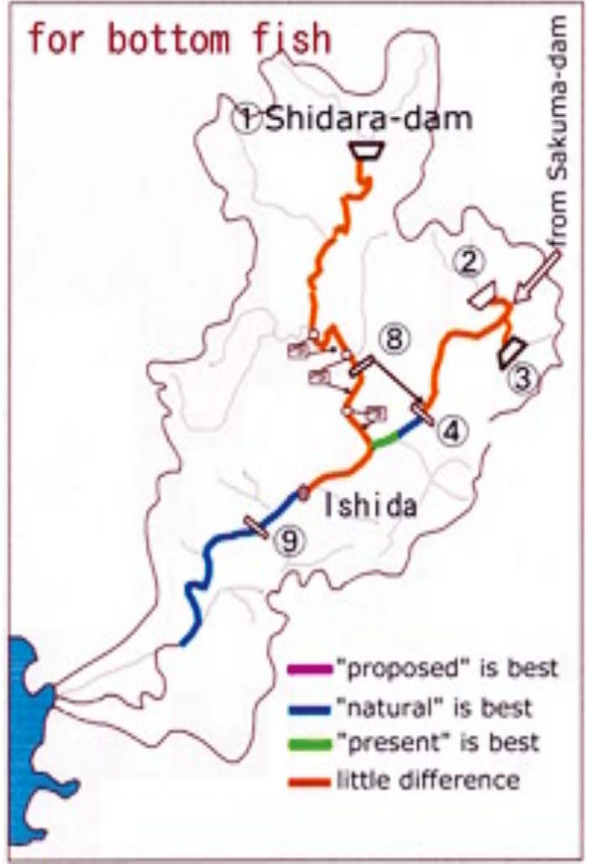

Fig. 18. - Summarized habitat change for major bottom fish in summer.

given by the proposed condition in the upstream portions of the Toyogawa, installation of fishways is strongly recommended at two power dams: Nagashima-dam and Furi-dam (another power dam: Yokogawa-dam already has a fishway).

\section{CONCLUSION}

This IFIM-style habitat assessment was submitted to the Toyohashi Branch of the Ministry of LIT and prepared for the Toyogawa River Basin's Future-Plan Reviewing Committee. Because no severe controversy oc- 
curred within the committee regarding the fish habitat changes, the habitat evaluation mentioned here was not sufficiently introduced to the public participants, and the new dam was accepted with little public involvement. However, we hope this kind of habitat evaluation will have another chance to be put to the best use in detailed discussions about future environmental problems in the Toyogawa.

\section{ACKNOWLEDGEMENTS}

The background work of this research was supported by Toyohashi Branch of the Ministry of LIT, Kasen-
Kankyou-Kanrizaidan, and NakanihonKensetsu Consultant. We would also like to thank Mr. M. Sekine (FISCO) for assisting with field work, and Prof. H. Asakusa (Tsukuba Technical College) for aiding in the WUA calculation.

\section{REFERENCES}

Asakusa, H., S. Nakamura. 2003. An assistant tool for public participation in reviewing river development planning, and its applications. In Prep.

Thomas, J.A. and K.D. Bovee. 1993. Application and testing of a procedure to evaluate transferability of habitat suitability criteria. Regulated Rivers: Research \& Management, Vol. 8, pp. 285-294. 